Şırnak Üniversitesi
Illahiyat Fakültesi Dergisi
Sayı $27 \quad$ Aralık 2021

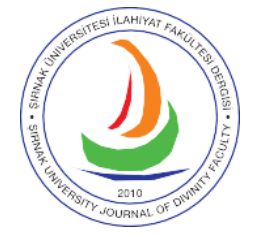

e-ISSN 2667-6575
Şırnak University

Journal of Divinity Faculty

Issue 27 December 2021

\title{
İslam Ekonomisi Açısından Türev Ürünlerin Eleştirel Bir Analizi
}

A Critical Analysis of Derivative Instruments from the Perspective of Islamic Economics

\section{Medine SICAKYÜZ}

Yüksek Lisans Öğrencisi, İstanbul 29 Mayıs Üniversitesi, Sosyal Bilimler Enstitüsü, İslam Ekonomisi ve Finans Anabilim Dalı

Master's Student, İstanbul 29 Mayıs University, Institute of Social Sciences, Department of Islamic Economics and Finance

İstanbul, Turkey

medinesicakyuz@gmail.com

https://orcid.org/0000-0002-1238-3307

\section{Harun ŞENCAL}

Dr. Öğr. Üyesi, İstanbul 29 Mayıs Üniversitesi, İktisadi ve İdari Bilimler Fakültesi, Ekonomi Anabilim Dalı

Assistant Professor, İstanbul 29 Mayıs University, Faculty of Economics and Administrative Sciences,

Department of Economics

İstanbul, Turkey

harun.sencal@gmail.com

https://orcid.org/0000-0003-3617-8954

\section{Makale Bilgisi / Article Information}

Makale Türü / Article Types: Araştırma Makalesi / Research Article

Geliş Tarihi / Received: 1 Ağustos / August 2021

Kabul Tarihi / Accepted: 3 Kasım / November 2021

Yayın Tarihi / Published: 15 Aralık / December 2021

Sayı / Issue: 27 Sayfa / Pages: 134-158

Atıf / Cite as: Sıcakyüz, Medine - Şencal, Harun. “İslam Ekonomisi Açısından Türev Ürünlerin Eleştirel Bir Analizi [A Critical Analysis of Derivative Instruments from the Perspective of Islamic Economics]". Şırnak Üniversitesi İlahiyat Fakültesi Dergisi - Şırnak University Journal of Divinity Faculty 27 (December 2021), 134-158. https://doi.org/10.35415/sirnakifd.977157

Etik Beyanı / Ethics Declaration: Bu makalede bilimsel araştırma ve yayın etiği ilkelerine riayet edilmiştir. Makale etik izin gerektirmeyen bir çalışma olup en az iki hakem tarafından incelenmiş ve intihal içermediği teyit edilmiştir./ In this article, the principles of scientific research and publication ethics are respected. The article is a study that does not require ethical permission. It has been reviewed by at least two referees and was confirmed that it did not contain plagiarism.

Copyright @ Published by Şırnak Üniversitesi, İlahiyat Fakültesi / Şırnak, Türkiye (Şırnak University, Faculty of Divinity, Şırnak, 73000 Turkey). 


\section{Özet}

Bu çalışmanın amacı modern zamana ait bir kavram olan riskin finansallaşan iktisadi sistem sonucunda metalaşmasını ve bu metalaşma sürecinin yol açtı̆̆ sonuçları İslam ekonomisi açısından eleştirel bir analize tabi tutmaktır. Modern öncesi dönemdeki belirsizliklerin modern dönemde -özellikle istatistik teorilerinin gelişmesi sayesinde- ölçülebilir ve nicel olarak ifade edilebilir bir karaktere sahip olmasıyla beraber hesaplanabilir belirsizlikler risk kavramına dönüşmüştür. İnsanlar tarafından üretilen ve küreselleşen dünyada artık "örtük" olarak tutulamayan riskler, Beck'in tabiriyle "Risk Toplumu" nu oluşturmuştur. Risk toplumunda artık bir meta haline gelen risk, neoliberal politikalar sayesinde finansallaşan iktisadi sistem içerisinde türev ürünler aracılığıyla kolay bir şekilde alınıp satılabilir bir hale gelmiştir. Teknolojinin sunduğu kolaylıklar ve hızlı işlem yapabilme imkânı finans piyasasının ürünlerini kullanarak sadece riski yönetme amacına değil bunun yanında risk üzerinden para kazanmak için işlem yapılması amacına da hizmet eder olmuştur. 20. yüzyılda tezgahüstü piyasalarda işlem görmeye başlayan türev ürünlerin temelde üç kullanım amacı vardır; hedging, spekülasyon ve arbitraj. Reel sektörün küreselleşen piyasalarda kaçınılmaz şekilde maruz kaldığı risk insanları hedging yapmaya iterken finansallaşma sayesinde ise spekülasyon ve arbitraj yaparak risk üzerinden para kazanmaya çalışan farklı bir kesim de ortaya çıkmıştır. Küreselleşmiş ekonomik sistem içinde ithalat ve ihracata dayalı ticaret yapan firmalar ticari faaliyetlerini istikrarlı şekilde yapabilmek ve ekonomik büyümelerini sağlayabilmek için kur riskinden korunmak zorundadır. Bunun neticesinde, küreselleşmenin oluşturmuş olduğu bu aşırı risk ortamında insanlar türev işlemler yaparak riskten korunmayı hedeflemektedir. Öte yandan, içinde bulunduğumuz finansal sistem reel mal üreten sektörlerin aksine spekülasyon ve beklentilerin hâkim olduğu bir sektördür; risk spekülasyonu ve beklentilere dayalı olan finansal sistem ise bütün piyasalarda belirleyici bir karaktere sahiptir. Türev ürünleri hedging amaciyla kullananlar için beklentiler olumsuzluk ifade ederken spekülatörler ve arbitrajcılar beklentilerin yarattığı risk ortamından faydalanan kesimdir. Çünkü spekülatörler ve arbitrajcılar rasyonel düşünceyi temel alarak -türev piyasalarında riskin metalaştırılması üzerinden- en az çaba ile en fazla kârı elde etmeyi hedeflemektedirler. Çalışmada türev ürünler sayesinde metalaşan riskin yol açtığı sorunların İslam ekonomisi açısından analizi yapılırken öncelikle finansallaşmanın sonuçları ele alınmış, ardından türev ürünlerin kullanımı İslam ekonomisi açısından değerlendirilmiştir. Toplumun finansal ihtiyaçlarını karşılamakta önemli bir yere sahip olan türev ürünler; sermaye sahiplerinin kolay yoldan kar elde etmek ve sermayesini arttırmak için spekülasyon ve arbitraj yapmasına olanak sağlayarak toplumda ekonomik adaletsizliği arttırmaktadır. Özetle toplumun ihtiyaçlarına hizmet etmesi gereken finansal sistem bunu sağlayamamakta, aksine spekülasyon gibi işlemlerin artması belli kişilerde sermayenin birikmesini sağlayarak toplumun ekonomik düzeninin daha kötüye gitmesine sebep olmaktadır. Her ne kadar ithalat ve ihracata dayanan ticari faaliyetler yapan firmalar kur riskiyle karşı karşıya olmaları sebebiyle türev ürünlere reel ekonominin istikrarı açısından ihtiyaç duysalar da türev ürünleri kullanan yatırımcılar bu amaçtan farklı olarak kısa sürede kar elde etmek için de bu araçları kullanmaktadır. Türev ürünlerin bu şekilde kullanımı ekonominin finansallaşmasını artırmakta ve reel üretime katkı sağlamaktan ziyade sermaye sahiplerinin sermayesini artırmasına aracılık yapmaktadır. Sermaye sahiplerinin kaynaklarını reel üretimden ziyade türev ve benzeri finansal ürünlere yönlendirmesi ise finansal krizler başta olmak üzere geniş ölçekte daha büyük sorunlara yol açmaktadır. Bu durum toplumsal maslahata uygun olmadığı ve İslam hukukundaki genel kabule göre toplumun maslahatı bireylerin çıkarından önce geldiği için türev ürünler maslahat açısından da uygun gözükmemektedir. Bu makalenin amacı, modern dönemde üretilmiş olan risklere karşı türev ürünler bir çözüm sunsa dahi, bu çözümün ekonominin daha fazla finansallaşmasına ve yatırımcıları İslam'ın maksatlarına uygun olmayan yollardan gelir elde etmeye yönelten bir finans ortamına yol açtığının vurgulanmasıdır. Türev ürünlerin fıkhi olarak değerlendirilmesine yer verilen bu çalışmada İslam hukukçularının daha ziyade sözleşme şartlarının İslam hukukuna uygunluğunu göz önüne aldıklarına dikkat çekilerek, bu gerekli şartın yanı sıra türev ürünlerin ortaya çıktığı bağlamın da fetva sürecinde değerlendirilmesinin önemine vurgu yapilmaktadir.

Anahtar Kelimeler: İslam Ekonomisi, Risk, Türev Ürünler, Finansallaşma, Küreselleşme. 


\section{Abstract}

The aim of this study is to critically analyze a modern concept -the commodification of risk as a result of the financialized economic system and the consequences of this commodification process from an Islamic economics perspective. As the uncertainties in the pre-modern period have a measurable and quantitative character in the modern period, especially thanks to the development of statistical theories, calculable uncertainties have turned into the concept of risk. Risks, which are produced by people and can no longer be kept "implicit" in the globalizing world, have formed the "Risk Society" in Beck's words. Risk, which has now become a commodity in the risk society, has become easily tradable via derivative instruments in the economic system that has become financialized thanks to neoliberal policies. The facilities offered by technology and the opportunity to make fast transactions have served not only to manage the risk by using the products of the financial market, but also to make transactions to earn money on risk. Derivative instruments, which started to be traded in the over-the-counter markets in the 20th century, have basically three uses: hedging, speculation, and arbitrage. While the risk that the real sector is inevitably exposed to in globalized markets pushes people to hedge, a different segment has emerged that tries to make money on risk by speculation and arbitrage thanks to financialization. In the globalized economic system, companies engaged in importing and exporting have to be protected from exchange rate risk to conduct their commercial activities in a stable manner and to ensure their economic growth. As a result, in this extreme risk environment created by globalization, people aim to avoid risk by making derivative transactions. On the other hand, contrary to the sectors that produce real goods, the financial system we are in is a sector dominated by speculation and expectations; The financial system, which is based on risk speculation and expectations, has a determining character in all markets. While expectations express negativity for those who use derivatives for hedging purposes, speculators and arbitragers are those who benefit from the risk environment created by negative expectations, since such investors with rational thought aim to gain the maximum profit with the least effort through commodification of risk in the derivatives market. In the study, to analyze the problems caused by commodification of the risk from an Islamic economics perspective, first, the consequences of financialization are discussed, and then how the derivative instruments have commodified the risk is evaluated. Derivative instruments, which have an important place in meeting the financial needs of the society, increase the economic injustice by enabling the capital owners to speculate and arbitrage to make profit easily and to increase their capital. In summary, the financial system that should serve the needs of the society cannot provide this; on the contrary, the increase in transactions such as speculation causes the accumulation of capital in certain people and causes the economic order of the society to deteriorate. Although companies engaged in commercial activities based on imports and exports need derivative instruments for the stability of the real economy due to the exchange rate risk, investors using derivative products also use these tools to make profit in a short time. The use of derivative instruments in this way increases the financialization of the economy and acts as an intermediary for the capital owners to increase their capital rather than contributing to real production. The fact that capital owners channel their resources to derivatives and similar financial instruments rather than real production causes bigger problems on a large scale, especially financial crises. Derivative instruments do not seem appropriate in terms of maslahā, since this situation is not suitable for public utility and, according to the general acceptance in Islamic law, the benefit of the society comes before the interests of individuals. The aim of this article is to emphasize that even if derivative instruments offer a solution to the risks produced in the modern period, this solution leads to more financialization of the economy and a financial environment that leads investors to earn income from ways that are not suitable for the purposes of Islam. In this study, which includes the evaluation of derivative instruments according to Islamic law, the importance of evaluating the context in which derivative instruments arise in the fatwa process is emphasized, along with the compliance of contract conditions with Islamic law.

Keywords: Islamic Economics, Risk, Derivatives, Financialization, Globalization. 


\section{Giriş $^{1}$}

Modern öncesi dönemde belirsizlik olarak ifade ettiğimiz gerçekleşme ihtimali bulunan olaylar için günümüzde çeşitli matematiksel hesaplamalar yapılabilmektedir. Bu sayede, istatistiksel olarak gerçekleşme ihtimali hesaplanan olaylar için belirsizlik yerine risk kavramı kullanılmaktadır. Özellikle 19.yy.'dan sonra doğal afetler gibi olayların dahi gerçekleşme ihtimalinin sayısal olarak hesaplanabilir kabul edilmesiyle risk kavramının kullanımı oldukça yaygınlaşmıştır. Artık örtük halde tutulamayan bu risklerin gündelik hayatın içerisinde herkesi etkileyecek seviyeye ulaşmasını Ulrich Beck "Risk toplumu"3 olarak kavramsallaştırmaktadır. Risk toplumunda sağlık, eğitim, sosyal hayat, ekonomi, finans gibi insanı ilgilendiren her alanda çeşitli risklerden söz edilebilir. Modern sonrası dönemde ortaya çıkan risk toplumunda, risklerin artık "örtük" 4 tutulamamasının sonucu olarak insanlar bu risklerden korunmaya ihtiyaç duymuşlardır. Örneğin 1970 tarihinde Bretton Woods anlaşmasının kullanımdan kalkmasından sonra kur riski oldukça artmış ve insanların kur riskinden korunma ihtiyacını ortaya çıkarmıştır. Bu durum hedging amaçlı türev ürünlerin kullanılmasını artırmıştır.

20.yy'ın sonlarına doğru hemen hemen tüm dünyada neoliberal politikaların uygulanmaya başlanması küreselleşmeyi ve beraberinde finansallaşmayı getirmiştir. Finansallaşma hem ulusal hem de uluslararası finansal işlemlerin ağırlığının artmasıdır. ${ }^{5}$ Finansal faaliyette bulunmayan işletmelerin de finansal piyasalar ile eskiye nispeten daha yoğun şekilde ilgilenmesi ve gelirlerinin giderek artan bir bölümünü finansal sektöre aktarmaya başlamasıdır.6 Günümüz ekonomisinde türev ürünlerin temel kullanım amacı hedging yaparak risk transferi sağlamanın yanı sıra ${ }^{7}$ spekülasyon ve arbitraj yaparak şirketlere

1 Bu makalenin önceki bir versiyonu "İslam Ekonomisi Açısından Türev Enstrümanlarının Eleştirel Bir Analizi" başlığıyla Uluslararası İslamî Sigortacılık ve Finans Sempozyumu'nda (25-26 Mart 2021) sözlü bildiri olarak sunulmuştur./ A previous version of this article was presented as a paper at the International Symposium on Islamic Insurance and Finance (March 25-26, 2021) with the title "A Critical Analysis of Derivative Instruments in terms of Islamic Economics".

2 Abdurrahim Emhan, "Risk Yönetim Süreci ve Risk Yönetmekte Kullanılan Teknikler”, Atatürk Üniversitesi İktisadi ve İdari Bilimler Dergisi 23/3 (Ağustos 2010), 221.

3 Ulrich Beck, Risk Toplumu ve Başka Bir Modernliği Doğru, çev. Bülent Doğan - Kazım Özdoğan (İstanbul: İthaki Yayınları, 2019), 8.

4 Beck, Risk Toplumu \& Başka Bir Modernliği Doğru, 12.

5 Özgür Orhangazi, “Keynesgil Finansal Düzenlemelerden Finansallaşmaya: İktisat Literatürü ve ABD Ekonomisinin Finansallaşmasına Tarihsel Bir Bakış”, ODTÜ Gelişme Dergisi 35 (Haziran 2008), 133.

6 Orhangazi, “Keynesgil Finansal Düzenlemelerden Finansallaşmaya: İktisat Literatürü ve Abd Ekonomisinin Finansallaşmasına Tarihsel Bir Bakış", 154.

7 Per Alkeback - Niclas Hagelin, "Derivative Usage by Nonfinancial Firms in Sweden with an International Comparison", Journal of International Financial Management \& Accounting 10/2 (1999), 113. 
kar elde etmek olmaya başlamıştır. ${ }^{8}$ Çünkü Dünya piyasalarında işlem yapabilme imkânı spekülatörler ve arbitrajcıların risk üzerinden para kazanmasına yardımcı olmaktadır. Bu çalışmanın amacı, modern dönemde ortaya çıkan bu risklerin finansallaşan iktisadi sistem içerisinde türev ürünler vasıtasıyla metalaşmasını ve bu durumun meydana getirdiği sonuçları İslam ekonomisi açısından analiz etmektir. Bu analiz yapılırken, türev ürünlerin fıkhi uygunluğunu tespit edebilmek için sözleşme şartları açısından İslam hukukuna uygunluğunun yanı sıra, türev ürünleri ortaya çıkaran bağlamın ve kullanılmalarının toplumsal düzeyde yol açacağı kısa ve uzun vadeli sonuçların da değerlendirilmesinin gerekliliği vurgulanacaktır.

Küreselleşmiş ekonomik sistem içinde ithalat ve ihracata dayalı ticaret yapan firmalar kur riskinden korunmak zorundadır. Çünkü riskten korunamadığında ve büyüme sağlayamadığında sistem içerisinde kalması zorlaşacaktır. Bu bağlamda türev ürünler reel ekonomideki faaliyetlerle yakından alakalı olup aynı zamanda -kurdaki dalgalanmalara karşıöngörülebilirliği artırıcı bir etkisi vardır. Öte yandan türev ürünler kullanılarak yapılan spekülasyonun ve arbitrajın artması ve finansal piyasaların geçmiş yıllara nazaran ekonomideki payının giderek büyümesi sermayenin reel piyasalardan ziyade finansal sektöre aktarılmasına yol açmaktadır. ${ }^{9}$

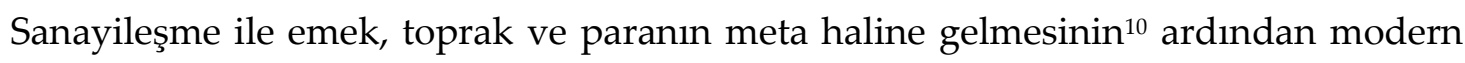
sonrası risk toplumunda risk de artık bir meta haline gelmiştir. Gerek finans piyasalarında gerek ticari sigorta sisteminde kolayca alınıp satılabilen risk, bir meta olarak reel faaliyete nazaran daha kısa sürede ve düşük maliyetle para kazanmayı sağlamaktadır. Finansal enstrümanların karlılığının ve verimliliğinin yüksek olması -küreselleşmenin de katkısıylafinansallaşmayı arttırarak reel ekonominin payını olumsuz yönde etkilemektedir. ${ }^{11}$ Hemen hemen her yüzyılda bir meydana gelen krizler de finansallaşmanın yol açtı̆̆ı olumsuzlukların sürdürülemez hale gelecek noktaya ulaşmasını temsil etmektedir.

Günümüzde -özellikle spekülasyon ve arbitraj amaçlı kullanılan- türev ürünler İslam'ın uygun gördüğü risk ve kar paylaşımına dayalı ekonomik faaliyetlerden oldukça farklıdır. İslam, toplumun ihtiyaçlarına yanıt verebilen ve toplumda ekonomik adaleti

\footnotetext{
Tor Brunzell vd., “The Use of Derivatives in Nordic Firms”, The European Journal of Finance 17/5-6 (2011), 358.

Brunzell vd., "The Use of Derivatives in Nordic Firms"; Stankovska, "Global Derivatives Market".

10 Karl Polanyi, Büyük Dönüşüm: Çă̆ımızın Siyasal ve Ekonomik Kökenleri, çev. Ayşe Buğra (İstanbul: İletişim Yayınları, 2010), 118.

11 Orhangazi, “Keynesgil Finansal Düzenlemelerden Finansallaşmaya: İktisat Literatürü ve ABD Ekonomisinin Finansallaşmasına Tarihsel Bir Bakış", 154.
} 
sağlayan iktisadi faaliyetleri uygun görür. ${ }^{12}$ Ancak bugün ekonomiyi etkileyen finans sisteminin "hatalı"13 olması sebebiyle görece küçük bir azınlık maksimum faydayı sağlarken toplumun geneli bu durumdan zarar gören taraftır. Eğer İslami bir ekonomiden bahsedeceksek bireysel çıkarlar için toplumsal maslahatın göz ardı edilmemesi gerekir.

Literatürde türev işlemleri fıkhi açıdan konu alan bazı çalışmalar ${ }^{14}$ türev işlemleri taraflardan birisi kazanç elde ederken diğer tarafın zarara uğradığ ${ }^{15}$ sıfır-toplamlı bir oyun olduğu için İslam’ın yasakladığı kumara benzetmiştir. Ekonomik olarak amaç sadece sermayenin bir grubun elinde toplanması ya da bir yerden bir yere aktarılmasıyla kalmamalı bunun ahlaki ilkelere uygun olup olmadığı, işlemin neden ve nasıl olacağı, bu sermaye aktarımının sonuçlarının toplumda ne gibi fayda ve zararlara yol açacağ dahil edilmelidir. Bu faktörler hesap edilmediği takdirde, toplumdaki ilişki ve kurumları belirleyen ilkelere göre şekillenen, diğer bir ifadeyle topluma gömülü olan ve toplumun ihtiyacına göre belirlenen iktisadi ilişkiler yerine, yönetici konumda olan ve kârın paydaşlara dağıtılmasının geri planda kaldığı bir ekonomik yapı ortaya çıkacak ve gelir eşitsizliği makası giderek açılmaya devam edecektir. ${ }^{16}$

Makalenin sonunda insanların içerisinde bulundukları riskten korunmalarının bir ihtiyaç olduğu kabul edilmiş ancak buna bir çözüm olarak ortaya çıkan türev ürünlerin çıkış bağlamını ve geleneksel finans sistemi içerisinde yol açtığı sorunları hesaba katarak bu ürünlerin İslam hukuku açısından uygunluğunu değerlendirmemiz gerektiği vurgulanmıştır. Bu sonuç bizi araştırmacıların mevcut ürünlerin İslam’a uygun hale getirilmesi için çaba sarf etmesinin yanı sıra İslam'ın uygun gördüğü toplumda ekonomik adaleti sağlayan ve toplumun ruhuna uygun, toplumu yönlendirmeyen aksine toplumun ihtiyaçlarına göre şekil alan risk paylaşımına dayalı ürün ve kurumların oluşturulması için çalışmalar yapmasının önemine götürmektedir.

12 Mehmet Asutay, "A Political Economy Approach to Islamic Economics: Systemic Understanding for an Alternative Economic System", Kyoto Bulletin of Islamic Area Studies 1/2 (2007), 7.

13 Robert J. Shiller, Finans ve İyi Toplum, çev. Erhan Akkaş (İstanbul: Albaraka Yayınları, 2019), 19.

14 Abdullah Durmuş, Fıkĥ̂ Açıdan Günümüz Para Mübadelesi İşlemleri (İstanbul: İsam Yayınları, 2014), 131; Servet Bayındır, "Finansal Türev Varlıklar ve Bu Varlıklar Üzerine Yapılan Sözleşmelerin Fıkhî Tahlili”, İstanbul Üniversitesi İlahiyat Fakültesi Dergisi 0/12 (Mayıs 2012), 72.

15 A.Kerem Özşahin, Vadeli İşlem Sözleşmesinin Hukuki Niteliği (Ankara: Sermaye Piyasası Kurulu, Yeterlilik Etüdü, 1999), 8.

16 Mehmet Asutay, "Conceptualising and Locating the Social Failure of Islamic Finance: Aspirations of Islamic Moral Economy Vs the Realities of Islamic Finance", Asian and African area studies 11/2 (2012), 97-100; Asutay, "A Political Economy Approach to Islamic Economics", 9-12. 


\section{Literatür Taraması}

Türev ürünlerin İslam hukuku açısından ele alındığı literatürü incelediğimizde, türev ürünlerin dayalı olduğu varlıklara göre değerlendirildiği ve forward, future, swap ve opsiyon ürünlerine odaklanıldığı görülmektedir. Bu alanda AAOIFI tarafından yayınlanan emtiaya dayalı türev ürünlere dair standart önemli bir kaynak oluşturmaktadır. ${ }^{17}$ Emtia haricinde, döviz, faiz oranı, endeksler, menkul kıymetler gibi çeşitli varlıklara dayalı türev ürünler piyasalarda bulunmaktadır. Bu çalışmanın amacı türev ürünlerin İslam hukuku açısından detaylı bir analizinden ziyade İslam hukukçularının hüküm verirken sözleşmenin şartlarına odaklandıklarını ve türev ürünlerin finansal piyasalar ve daha genel olarak ekonominin finansallaşması bağlamında oynadığı role değinmediklerini göstermek olduğu için literatür taramasını emtia, döviz ve faiz oranı varlıklarına dayalı türev ürünlerle sınırlamaktayız. Bu konudaki görüşler aşağıda detaylı olarak ele alacağımız (i)caiz görmeyenler ve (ii)caiz görenler şeklinde iki alt başlıkta sunulmaktadır.

\subsection{Caiz Görmeyenler}

Faiz oranına dayalı türev ürünler; İslam'ın faizi yasaklamış olması sebebiyle faize dayalı türev ürünleri fazla tartışma konusu olmamıştır. Araştırmalarımız neticesinde ulaştığımız literatürde bu konuyu ele alan çalışmaların faiz oranı üzerine yapılan sözleşmelerin caiz olmadığı konusunda uzlaştığı görülmektedir. Bunun sebebi, faiz oranına dayalı forward ve future sözleşmelerinde alım-satıma konu olan varlığın borcun satımından ortaya çıkan faiz oranı olması ve faiz oranlarının İslam hukukuna göre alım-satım konusu olmaya uygun (mütekavvim) bir mal kabul edilmemesidir. ${ }^{18}$ Faiz İslam hukuku açısından yasak olduğundan dayanak varlığı faiz olan swap sözleşmeleri de kesinlikle yasaktır. ${ }^{19}$

Emtiaya dayalı türev ürünler; Forward sözleşmeleri; fiyatı ve miktarı bugünden belirlenmiş olan dayanak varlığın önceden belirlenmiş bir kur üzerinden ileri bir tarihte alımsatımının yapılacağı anlaşmalardır. ${ }^{20}$ Future sözleşmeler ise forward sözleşmelerin

17 Faizsiz Finans Kuruluşları Muhasebe ve Denetleme Kurumu (AAOIFI), Faizsiz Finans Standartları (İstanbul: Türkiye Katılım Bankaları Birliği Yayınları, 2015, Yayın no:10), 529-546.

18 Bayındır, "Finansal Türev Varlıklar ve Bu Varlıklar Üzerine Yapılan Sözleşmelerin Fıkhî Tahlili”, 65-66; Aytaç Aydın, İslam Hukuku Açısından Mali Piyasa ve Mali Piyasa Araçları (Konya: Burç Yayınevi, 2015), 516.

19 Muhammad Al-Bashir Muhammad Al-Amine, İslami Finansta Risk Yönetimi \& Emtia Piyasalarındaki Türev Ürünler Üzerine Bir İnceleme, çev. Ali Kürşat Sak - Gencay Karakaya (İstanbul: Albaraka Yayınları, 2020), 344; Aydın, İslam Hukuku Açısından Mali Piyasa ve Mali Piyasa Araçları, 522.

20 Mahfi Eğilmez, Ekonominin Temelleri (Kavramlar ve Kurumlar) (İstanbul: Remzi Kitabevi, 2019), 345. 
standartlaştırılmış ve organize piyasalarda işlem gören halidir. ${ }^{21}$ İslam hukukuna göre sözleşmelerde emtia teslimi ve para değişiminden en az biri sözleşme anında yapılması gerektiği halde forward sözleşmeler (veya forward sözleşmelerin standartlaştırılmış hali olan future sözleşmeler) her iki bedelin de ertelendiği bir alım-satım olduğu için İslami açıdan caiz görülmemektedir.22 Diğer yandan işlem sonunda teslim-tesellüm yükümlülüklerinin yerine getirilmemesi de fıkhi açıdan itirazlara sebep olmaktadır. ${ }^{23}$ Ayrıca, müşterinin emtiayı teslim almasına engel olabilecek herhangi bir şartın sözleşmede yer almaması gerekir. ${ }^{24}$ Borsada gerçekleşen emtia vadeli işlemlerde genellikle (\%97) ters işlem ve nakdi uzlaşma ile sonlanmasından anlaşıldığı üzere fiziki teslim amaçlanmamakla birlikte sonunda bir kazananın karşısında mutlaka bir kaybedenin olduğu işlemler olması sebebiyle de caiz kabul edilmez. ${ }^{25}$ Fıkhen meşru sayılmayan emtianın alım satımının yapıldığı vadeli sözleşmeler ise zaten meşru kabul edilmemektedir. ${ }^{26}$

Swap sözleşmeleri taraflar arasında belirli miktardaki finansal varlıkların, malların ya da faizlerin geçici olarak takas edilmesi üzerine yapılan anlaşmalardır. ${ }^{27}$ Swaplar, tıpkı forward sözleşmelerde olduğu gibi, standart olmayan sözleşmelerdir ve taraflar arasında anlaşılarak yapılır.. ${ }^{28}$ AAOIFI'nin standardına göre emtia piyasalarında uygulanan şekliyle swap işlemleri fıkhen caiz görülmemektedir. ${ }^{29} \mathrm{Bu}$ hükmün temel sebepleri; işlemlerde fiili takasın gerçekleşememesi, işlem sonlanırken faiz oluşması, her iki bedelin de vadeli olması şeklindedir. ${ }^{30}$

Döviz; Bir döviz satış (sarf) akdi gerçekleşmişse faiz oluşmaması için taraflar birbirlerinden ayrılmadan önce bedeller karşılıklı olarak teslim edilmelidir. ${ }^{31}$ Dövizin vâdeli satımı olan forward işlemlerinde ise bedeller karşılıklı olarak teslim edilmediğinden dolayı

21 Ahmet Aksoy - Cihan Tanriöven, Sermaye Piyasası Yatırım Araçları ve Analizi (Ankara: Gazi Kitabevi, 2007$), 489$.

22 Faizsiz Finans Kuruluşları Muhasebe ve Denetleme Kurumu (AAOIFI), Faizsiz Finans Standartları, 536; Aydın, İslam Hukuku Açısından Mali Piyasa ve Mali Piyasa Araçları, 511-512.

23 Şamil Şahin, “Ukûdü'l-müstakbeliyyât fi's-sila'”, İslam Medeniyet Dergisi 7/47 (Haziran 2021), 69.

24 Faizsiz Finans Kuruluşları Muhasebe ve Denetleme Kurumu (AAOIFI), Faizsiz Finans Standartları, 535.

25 Abdullah Durmuş, “Döviz Vadeli ve Emtia Vadeli İşlem Sözleşmeleri”, II. Uluslararası İslam Ticaret Hukuku Kongresi "Günümüzdeki Meseleler", ed. Mehmet Bayyiğit (Konya: KTO Karatay Üniversitesi Yayınları, 2016), 987988; Şahin, “Ukûdü'l-müstakbeliyyât fi's-sila'”, 66.

26 Faizsiz Finans Kuruluşları Muhasebe ve Denetleme Kurumu (AAOIFI), Faizsiz Finans Standartları, 537; Durmuş, “Döviz Vadeli ve Emtia Vadeli İşlem Sözleşmeleri”, 987.

27 Yalçın Karatepe, Türev Piyasaları (Ankara: Ankara Üniversitesi Siyasal Bilimler Fakültesi Yayını, 2000, Yayın no:587), 147.

28 Karatepe, Türev Piyasaları, 150.

29 Faizsiz Finans Kuruluşları Muhasebe ve Denetleme Kurumu (AAOIFI), Faizsiz Finans Standartlart, 541.

30 Faizsiz Finans Kuruluşları Muhasebe ve Denetleme Kurumu (AAOIFI), Faizsiz Finans Standartları, 546.

31 Nuri Kahveci (ed.), İslam Hukuku (Eşya-Borçlar-Şirketler) (İstanbul: Hikmetevi Yayınları, 2020), 1/248. 
faiz meydana gelmektedir. ${ }^{32}$ Dövize dayalı forward işlemlerin caiz görülmemesinin bir diğer gerekçesi ise bu akdin yasak kabul edilen borcun borç karşılığı satımına sebep olmasıdır. ${ }^{33}$

İşlemin faiz içermesi sebebiyle caiz kabul edilmemesinin yanında bazı araştırmacılara göre forward işlemi faizli bir akit değil garar içeren bir akittir ve döviz kurunun oluşturduğu riskten faydalanarak spekülasyon ve arbitraj amaçlı işlem yapmak caiz değildir. ${ }^{34}$ Ancak forward işlemlerinin günümüz ticaret uygulamaları çerçevesinde hedging amaçlı kullanılması caiz kabul edilmektedir. ${ }^{35}$ Riskten korunma amacıyla kullanılabilmesinin meşru olması konusunda günümüz İslam hukukçuları arasında farklı görüşler bulunmaktadır. Örneğin Durmuş'a göre kur riskinden korunma ihtiyacı içinde olanlar için kısmen menfaat ve maslahat bulunsa dahi vadeli döviz işlemleri faiz içermesinden dolayı toplumun geneline zarar vermektedir ve kur riski ile karşı karşıya olanların başka alternatiflere yönelerek bu ihtiyaçlarını karşılamaları gerekir. ${ }^{36}$ Aynı şekilde Sâlus da zaruret halinde (kur riskinden korunma amacıyla) dahi olsa bu işlemlerin caiz olmayacağ görüşündedir. ${ }^{37}$

Dayanak varlık olarak döviz kullanan swap türü işlemin ikinci aşamasında fâiz var olduğundan ve döviz işlemlerinin faiz oluşmaması için spot yapılması gerektiği gerekçeleriyle fıkhi olarak meşru görülmemektedir..$^{38}$

Opsiyon bir satın alma veya satma hakkı için belli bir bedel ödenmesi işlemini ifade ettiği için faiz oranı sözleşmelerinde, emtia sözleşmelerinde ve döviz sözleşmelerinde aynı işlevi görmektedir. Opsiyon sözleşmeleri sayesinde opsiyon alıcısı belirli bir bedel karşılığında opsiyon konusu malı belirlenen tarihte alma ya da satma hakkı kazanmıştır. ${ }^{39}$ Opsiyon işlemi karşılı̆̆ında bedel almak için uygun bir konunun bulunmadı $\breve{g}^{40}$, muhayyerlik hakk1

31 Bayındır, “Finansal Türev Varlıklar ve Bu Varlıklar Üzerine Yapılan Sözleşmelerin Fıkhî Tahlili”, 73; Durmuş, Fıkĥे Açıdan Günümüz Para Mübadelesi İşlemleri, 97; İshak Emin Aktepe, Sorularla Katılım Bankacılı̆̆ı (İstanbul: Türkiye Katılım Bankaları Birliği, 2013), 57; Hamdi Döndüren, Ticaret ve İktisat İlmihali (İstanbul: Erkam Yayınları, ts.), 660; Ali Ahmed Sâlûs, el-Muâmelâtü'l-mâliyye el-muâstra fì mîzâni'l-fikhi'l-İslâmî (Kuveyt: Mektebetül'1-Fellah, 1992), 198; Ali Muhyiddin Karadâği, ““el-Esvâkü'l-mâliyye fî mizâni'l-fıkhi'l-İslâmî”, Mecelletü Mecmai'l-Fıkhi'l-İslâmî 7/1 (1992), 169.

33 Muhammed Takî el-Osmânî, “Ukûdü'l-müstakbeliyyât fi's-sila'”, Mecelletü Mecmai'l-Fıkhi'l-İslâmî 1/7 (1992), 350.

34 Aktepe, Sorularla Katılım Bankacılı̆̆ı, 57.

35 Aktepe, Sorularla Katılım Bankacılı̆̆ı, 57.

36 Durmuş, Fıkhî Açıdan Günümüz Para Mübadelesi İşlemleri, 100.

37 Sâlûs, el-Muâmelâtü'l-mâliyye el-muâsıra fî mîzâni'l-fikhi'l-íslâmî, 197.

38 İshak Emin Aktepe, Katılım Finans (İstanbul: Türkiye Katılım Bankaları Birliği Yayınları, 2017, 09), 141; Durmuş, Fıkhî Açıdan Günümüz Para Mübadelesi İşlemleri, 102; Muhammad Al-Amine, İslami Finansta Risk Yönetimi E Emtia Piyasalarındaki Türev Ürünler Üzerine Bir İnceleme, 344; Aydın, İslam Hukuku Açısından Mali Piyasa ve Mali Piyasa Araçları, 524.

39 Eğilmez, Ekonominin Temelleri (Kavramlar ve Kurumlar), 349.

40 Durmuş, Fıkhî Açıdan Günümüz Para Mübadelesi İşlemleri, 139; Aydın, İslam Hukuku Açısından Mali Piyasa ve Mali Piyasa Araçları, 518; Durmuş, “Döviz Vadel ve Emtia Vadeli İşlem Sözleşmeleri”, 988. 
karşılığında bedel (opsiyon primi) almanın caiz olmadığı, ${ }^{41}$ bu işlem ile insanların mallarının batıl yollarla alınmış olduğu, ${ }^{42}$ işlemin garar ve riba içerdiği gerekçeleriyle caiz görülmemektedir.43 Çalışmalarda opsiyon primi ile kaparo karşılaştırılmış ve satış gerçekleşirse alınan bedelin kaparoda olduğu gibi satış bedeline eklenmemesi gerekçesiyle iki işlemin birbirinden farklı olduğu sonucuna ulaşılmıştır. ${ }^{44}$ Döviz opsiyon özelinde konu ele alındığında ise sarf işlemlerinde vade caiz görülmediği için muhayyerlik ve kaparo da kabul edilemez. ${ }^{45}$ Diğer yandan bu görüşe sahip olanların başka bir sebebi de işlemi yapan her iki tarafın da kendisinin karlı çıkacağını düşünmesi ancak vade sonunda sadece bir tarafın karlı çıkmasıyla işlemin kumara oldukça benzer özellikler taşıdı̆̆ı iddiasıdır. ${ }^{46}$ Ayrıca AAOIFI tarafından bu vaadin ikincil piyasada da satımının meşru olmadığı vurgulanmaktadır. ${ }^{47}$

\subsection{Caiz Görenler}

Emtia; Mütekavvim bir malı konu alan vadeli işlemlerde her iki bedelin vadeli olması ticari bir gerekliliğe dayanıyorsa ve amaç spekülasyon yaparak gelir elde etmek değilse işlem caiz görülebilir. ${ }^{48}$ Abdülbarî Meş'al' de emtia vadeli işlemlerin ihtiyaç halinde ihtiyatla caiz olabileceği görüşündedir. ${ }^{49}$ Başka bir çalışmaya göre forward sözleşmeleri şu şartları içerdiği sürece işlemin caiz olduğu düşünülebilir; işleme konu olan mal İslam hukukunda alım-satımı caiz görülen bir mal olmalıdır, bedellerden biri peşin olmalıdır, süre malum olmalıdır, süre sonunda söz konusu malı satın almak zorunlu olmalıdır ve sözleşmede geri dönüşü olmayan teminat (depozit) şartı bulunmamalıdır. ${ }^{50}$

Emtia forward sözleşmelerinin caiz olması ya da olmaması noktasındaki asıl mesele bu işlemin selem, istisna', borcun borç karşılığı satışı açılarından ele alındığında nasıl bir sonuca ulaşıldığı ile ilgilidir. Emtia forward sözleşmeleri ile selem akdinin karşılaştırması yapıldığında en önemli sorunlardan biri Müslüman çoğunluğun kabulüne göre selem akdinde bedelin anlaşma anında yapılması gerektiğidir. ${ }^{51}$ Selem akdinde bedelin sözleşme anında

\footnotetext{
es-Sıddîk Muhammed el-Emîn ed-Darîr, "el-İhtiyârât”, Mecelletü Mecmai'l-Fıkhi'l-İslâmî 7/1 (1992), 263.

Karadâği, “"el-Esvâkü'l-mâliyye fî mizâni'l-fikhi'l-İslâmî”, 180.

Durmuş, Fıkhî Açıdan Günümüz Para Mübadelesi İşlemleri, 131,139.

Aydın, İslam Hukuku Açısından Mali Piyasa ve Mali Piyasa Araçları, 519.

Durmuş, “Döviz Vadeli ve Emtia Vadeli İşlem Sözleşmeleri”, 987.

Durmuş, Fıkhî Açıdan Günümüz Para Mübadelesi İşlemleri, 131.

Faizsiz Finans Kuruluşları Muhasebe ve Denetleme Kurumu (AAOIFI), Faizsiz Finans Standartları, 540.

Durmuş, “Döviz Vadeli ve Emtia Vadeli İşlem Sözleşmeleri”, 987.

Durmuş, “Döviz Vadeli ve Emtia Vadeli İşlem Sözleşmeleri”, 1158.

Aydın, İslam Hukuku Açısından Mali Piyasa ve Mali Piyasa Araçları, 516.

51 Muhammad Al-Amine, İslami Finansta Risk Yönetimi \& Emtia Piyasalarndaki Türev Ürünler Üzerine Bir İnceleme, 74 .
} 
ödenmesinin zorunlu olmasının sebebi borcun borç karşılığında satımının fıkhen yasak olmasıdır. ${ }^{52} \mathrm{Al}$-Amine ise bu konuda Malikilerin selem akdinde bedelin geciktirilmesine izin verdiği görüşüne dayanarak emtia forward işlemini seleme klyas ederek işlemin caiz olduğu kanaatindedir. ${ }^{53}$ Bunun yanında, emtia forward sözleşmesi istisna' akdinin bir benzeri olduğu iddia edilerek de caiz görülmektedir. ${ }^{54}$

Benzer şekilde emtia forward işlemlerini caiz gören Hashim Kamali, emtia sözleşmelerinin yalnızca \%2'sinin fiili teslimatla sonlanmasını bir sorun olarak görmemekte, emtia forward işlemlerini sonlandırırken ters işlem yapmanın bu akdin caiz olmasının önünde bir engel olmadığını iddia etmektedir. ${ }^{55}$ Çünkü Kamali'ye göre emtia forward işlemlerini değerlendirirken dikkat edilmesi gereken husus teslimin gerçekleşme şekli değil, bu sözleşmenin temelinde olan borcun satılması durumunun İslam hukuku açısından hükmüdür. ${ }^{56}$ Kamali'ye göre borcun satılması işlemiyle ilgili ise açık bir yasaklama yoktur ve bu işlemde takas odasının kullanılıyor olması sayesinde işlemin yasak olmasına sebebiyet verebilecek garar ve riba da bulunmamaktadır. ${ }^{57} \mathrm{Bu}$ sebeple, Kamali'ye göre, emtia forward işlemleri caizdir.

Döviz; İbn Şinkiti ve Kuveyt Finans Kurumu Fetvâ Heyeti'ne göre ise forward ve future döviz işlemlerinde bir akitleşme değil vaadleşme gerçekleşmektedir. ${ }^{58}$ Kuveyt Finans Kurumu Fetvâ Heyeti riskten korunma amacıyla işleme konu olan malın fiyatının, miktarının ve niteliğinın başlangıçta belirlenerek ileri bir tarihte teslim-tesellümün yapılması şartıyla forward sözleşmelerin yapılmasını uygun bulmakla birlikte, işlemi yapan tarafların karşılıklı vaadleşmesi yerine, tek taraflı bir vaad ile vaadi veren tarafın vaadinden dönme imkanının olduğu bir sözleşme olması gerektiğini vurgulamaktadır. ${ }^{59}$

52 Burhânüddîn Alî b. Ebî Bekr EL-Mergînânî, El-Hidaye Tercümesi, çev. Hüseyin Vanlığlu vd. (İstanbul: Yasin Yayınevi, 2017), 4/382.

53 Muhammad Al-Amine, İslami Finansta Risk Yönetimi \& Emtia Piyasalarındaki Türev Ürünler Üzerine Bir İnceleme, $77,86$.

54 Muhammad Al-Amine, İslami Finansta Risk Yönetimi \& Emtia Piyasalarındaki Türev Ürünler Üzerine Bir İnceleme, 87.

55 Mohammad Hashim Kamali, İslam Ticaret Hukuku Vadeli İşlem Sözleşmeleri ve Opsiyonların Analizi, çev. Nazan Lila (İstanbul: Albaraka Yayınları, 2020), 174, 175.

56 Kamali, İslam Ticaret Hukuku Vadeli İşlem Sözleşmeleri ve Opsiyonlarmn Analizi, 175.

57 Kamali, İslam Ticaret Hukuku Vadeli İşlem Sözleşmeleri ve Opsiyonların Analizi, 182-184.

58 Durmuş, Fikhî Açıdan Günümüz Para Mübadelesi İşlemleri, 75.

59 Bayındır, "Finansal Türev Varlıklar ve Bu Varlıklar Üzerine Yapılan Sözleşmelerin Fıkhî Tahlili”, 70. 
Ayrıca döviz forward işleminin caiz görülmesinin bir başka sebebi de bu sözleşmelerin amacının dövizi bir emtia olarak kullanıp yasak kabul edilen döviz ticareti yapmak değil piyasadaki dalgalanmalardan kaynaklanan riskten karşılıklı olarak korunmak olduğudur. ${ }^{60}$

Ürdün İslam Bankası'nın fıkıh heyeti ise Hanefi ve Şafi'lere göre sarf akdinde rayiç kurdan farklı bir kur kullanılabileceğini ileri sürerek döviz türev işlemlerinin caiz olduğu şeklinde karar belirtmiştir. ${ }^{61}$ Durmuş'a göre ise kurun serbest belirlenebilmesi fakihlerin üzerinde ittifak ettiği sarf akdinin peşin olması şartı ile çelişmekte ve vadeli döviz işlemlerinin caiz görülmesi için yeterli bir argüman değildir. ${ }^{62}$ Musa Âdem İsa'ya göre ise toplumda genel bir ihtiyaç bulunduğu için bu işlemler caiz olmalıdır. ${ }^{63}$

Bayındır döviz swap işleminin her iki tarafa da menfaat sağlayan karşılıklı karz niteliğinde olduğu tespitinde bulunmuş ve faiz borcu swabı olmaması şartıyla döviz swap işlemlerinin caiz olduğunu belirtmiştir. ${ }^{64}$ Ancak bazı çalışmalarda döviz swap işleminin ilk kısmı (spot) caiz görülmekle birlikte ikinci kısmında caiz kabul edilmeyen vadeli döviz işlemi (döviz forward işlemi) bulunduğu için döviz swap işlemleri de caiz görülmemiştir. ${ }^{65}$

Muhayyerlik hakkı veya urban olarak ifade edilen opsiyon işlemi hem riskten korunma sağladığı hem de satıcının alıcıya sağladığ gerekçeleriyle caiz görülmektedir. ${ }^{66} \mathrm{Bu}$ görüşe sahip olanlara göre opsiyon karşılığında bedel alınabilir bir mal olarak kabul edilmektedir. ${ }^{67}$

Yapılan çalışmalar incelendiğinde türev ürünlerin kullanımı için fetva verilirken değerlendirmelerin sözleşme bazlı ele alındığı dikkat çekmektedir. Türev ürünlerin ortaya çıktığı finansal iktisadi ortam ve yapılan işlemlerin ekonomi ve toplum üzerindeki sonuçlarının neler olabileceği ise genel olarak değerlendirmede zikredilmemektedir. Öyle ki türev ürünlerin aşırı belirsizlik içermesi caiz kabul edilmemesinin sebeplerinden biridir. Fakat şu unutulamamalıdır ki türev ürünler zaten riskler üzerinden kazanç elde edilmeye çalışılan işlemlerdir. Riskin bir meta olarak alınıp satılması neticesinde türev işlemler yapılmaktadır. Herhangi bir konuda fetva verilirken akit çerçevesinde inceleme yapılırken aynı zamanda

60 Muhammad Al-Amine, İslami Finansta Risk Yönetimi \& Emtia Piyasalarnndaki Türev Ürünler Üzerine Bir İnceleme, 136.

61 Durmuş, Fıkhî Açıdan Günümüz Para Mübadelesi İşlemleri, 76.

62 Durmuş, Fıkhî Açıdan Günümüz Para Mübadelesi İşlemleri, 97.

63 Durmuş, Fıkĥ̂ Açıdan Günümüz Para Mübadelesi İşlemleri, 98.

64 Bayındır, "Finansal Türev Varlıklar ve Bu Varlıklar Üzerine Yapılan Sözleşmelerin Fıkhî Tahlili”, 68.

65 Durmuş, Fıkĥ̂ Açıdan Günümüz Para Mübadelesi İşlemleri, 102.

66 Kamali, İslam Ticaret Hukuku Vadeli İşlem Sözleşmeleri ve Opsiyonların Analizi, 272.

67 Kamali, İslam Ticaret Hukuku Vadeli İşlem Sözleşmeleri ve Opsiyonların Analizi, 266, 273. 
toplumsal sonuçların da hesaba katılması İslam ekonomisi açısından önemli bir noktadır. ${ }^{68} \mathrm{Bu}$ sebeple, bu çalışmada türev ürünlerin sözleşme bağlamında İslam hukukuna uygunluğu açısından değerlendirilmesinin yanı sıra literatürdeki önemli bir boşluğu doldurmak adına ilk olarak türev ürünlerin ortaya çıkışı ve riskin metalaşması ele alınarak bu metalaşmanın ekonomideki zararları üzerinde durulmuştur. Bu çalışmanın amacı, türev ürünlerin İslam ekonomisi açısından uygunluğunu ele alabilmek için ilk olarak türev ürünlerin ortaya çıktığı bağlamın tespit edilerek İslam ekonomisi açısından bir değerlendirmesinin yapılması ve sonrasında türev ürünlerin reel sektörde faaliyet gösteren şirketler için -uzun vadede- İslami bir çözüm olup olamayacağının tartışılmasıdır. Makalenin sınırları alternatif çözümler önermeye yeterli olmadığı için ilerideki çalışmalara yol göstermek adına zarureten veya maslahata dayanılarak verilen İslami açıdan uygun değerlendirmeler yerine şirketlerin içerisinde bulunduğu duruma, finansal piyasaların bağlamını da göz önüne alarak İslami ilkelere uygun kurum önerileri getirilmesinin önemine dikkat çekilmek amaçlanmaktadır.

\section{Risk Kavramı}

Risk, olasılık ve belirsizlik kavramları birbirleriyle ilişkili olduğundan aradaki farklar genelde ayırt edilmemekte ve bu kavramlar birbirlerinin yerine kullanılabilmektedir. ${ }^{69}$ Ancak belirsizlik ve riskin zaman zaman birbirinin yerine kullanılıyor olmasına rağmen aralarında istatiksel bir fark bulunmaktadır. Ayrıca insanlık tarihi kadar eski olan riskin, çağlar öncesindeki kullanımıyla bugünkü kullanımı arasında da içerik ve anlam yönünden farklılıklar vardır. ${ }^{70}$ Modern öncesi dönemde kullanılan riskten kastedilen şey genellikle gerçekleşme olasılığı bilinemeyen bugün belirsizlik olarak ifade ettiğimiz olaylardır. Risk kelimesi geleneksel toplumdan modern topluma geçiş sürecinde önemli bir kullanım alanına kavuşmuştur. ${ }^{71}$ Bugün artık istatistiksel olarak hesaplanan olaylar için risk, istatistiksel olamayan olaylar için belirsizlik kavramı kullanılmaktadır. ${ }^{72}$ Modern öncesi zamanlarda belirsizlik daha çok insanların üstesinden gelmek için çabalamadığı doğa olayları, felaketler veya tanrısal nedenlerle oluşmuş olayları ifade eder ve kader olarak nitelendirilirdi. ${ }^{73}$

68 Ahmet Yaman, "Yeni Zamanlarda Fetvaya Ne Oldu? Günümüz Fetvalarında Görülen Bazı Yöntem Sorunları”, Türkiye Araştırmaları Literatür Dergisi 13/25-26 (2015), 30-31.

69 Emhan, “Risk Yönetim Süreci ve Risk Yönetmekte Kullanılan Teknikler”, 210.

70 Aysu Çuhacı, “Ulrich Beck'in Risk Toplumu Kuramı”, İstanbul Üniversitesi Sosyoloji Dergisi 3/14 (Şubat 2012), 134.

71 Suat Soydemir, "Modernizmin Karanlık Yüzü: Risk Toplumu”, Sosyal ve Beşerî Bilimler Dergisi 3/2 (01 Aralık 2011), 170.

72 Emhan, “Risk Yönetim Süreci ve Risk Yönetmekte Kullanılan Teknikler”, 211.

73 Soydemir, “Modernizmin Karanlık Yüzü: Risk Toplumu”, 170. 
Belirsizlik olarak nitelendirdiğimiz olaylar elbette modern dönemde de mevcuttur ancak bunların istatistiksel olarak hesaplanmaya başlanması ve sigorta gibi uygulamaların kullanımının yaygınlaşmasıyla birlikte gerçekleşme olasılığı hesaplanabilen belirsizlikler artık risk olarak ifade edilmektedir. Modern toplumlarda riskler insan üretimi olarak bulunurken modern öncesi toplumlarda riskler insan ürünü olmayıp dışsal niteliklidir ve kadere bağlı veya Tanrısal sayılırlar. ${ }^{74}$ Akılıı düşünce ve bilimsel bilginin hâkim olduğu modern zamanda risklerin insan eliyle üretilmiş ve hesaplanabilir olması onlarla başa çıkılabilir, en azından zararı azaltılabilir olduğu anlayışını meydana getirmiştir. ${ }^{75}$

Günümüz toplumunu risk toplumu olarak adlandıran ve farklı açılardan da olsa risk kavramını ele alan iki önemli isim vardır: Anthony Giddens ve Ulrich Beck. Giddens'a göre modern zaman öncesinde belirsizlikleri ifade eden riskler dışsal risklerken, modern sonrasındaki riskler üretilmiş risklerdir. Modern dönemden önce insan toplumları insan üretimi olmayan dışsal risk dediğimiz kuraklık, deprem, açlık, fırtına gibi tehlikelerle karşı karşıyayd1. ${ }^{76}$ Ancak bugün kendi bilgimizin ve teknolojimizin doğal dünya üzerindeki etkisi sebebiyle ortaya çıkan ve gitgide artan riskler ile karşı karşıyayız. ${ }^{77}$ Modern dönemin başlarında insanlar tarafından üretilen ve örtük yan etkilere sahip olan bu riskler, Beck tarafından "risk toplumu" olarak kavramsallaştırılan günümüz toplumunda hayatın merkezinde yer almaya başlamıştır. Modern toplumun en önemli özelliği ise üretilmiş riskleri kontrol altına almayı amaçlamasıdır. ${ }^{78} \mathrm{Bu}$ yüzden risk toplumundaki insanlar için oluşabilecek tehlikeleri önceden görme ve onlara tahammül etme ile onlarla başa çıkma yeteneği önem kazanmıştır. ${ }^{79}$

Modern sonrası risk toplumunda riskler belirli bir mekân ile sınırlandırılamaz. ${ }^{80} \mathrm{Bu}$ duruma Bretton Woods ${ }^{81}$ sisteminin kaldırılmasından sonra ekonomide oluşan risk ortamı, neoliberal politikalar ve finansallaşmayla birlikte ekonominin küreselleşmesi örnek olarak verilebilir. Bretton Woods sisteminin çökmesiyle para birimlerinin altınla olan bağının

\footnotetext{
74 Ali Esgin, “İmal Edilmiş Belirsizlikler Çă̆ının Sosyolojik Yönelimi: Ulrich Beck ve Anthony Giddens Kaynaklı 'Risk Toplumu' Tartışmaları”, Gaziantep University Journal of Social Sciences 12/3 (Aralık 2013), 687.

75 Engin Yıldırım, “Risk Toplumunda (Depremle) Yaşamak”, Akademik İncelemeler Dergisi 3/1 (Ağustos 2014), 76,77 .

76 Anthony Giddens, Sosyoloji, çev. Hüseyin Özel vd. (İstanbul: Kırmızı yayınları, 2012), 1006.

77 Giddens, Sosyoloji, 1006.

78 Esgin, “İmal Edilmiş Belirsizlikler Çă̆ının Sosyolojik Yönelimi: Ulrich Beck ve Anthony Giddens Kaynaklı ‘Risk Toplumu' Tartışmaları", 687.

79 Beck, Risk Toplumu E Başka Bir Modernliği Doğru, 115.

$80 \quad$ Beck, Risk Toplumu E Başka Bir Modernliği Doğru, 27.

80 Bu konuda detaylı bilgi için bkz. Zeynel Dinler, İktisada Giriş (Bursa: Ekin Yayınevi, 2019), 606-610.
} 
çözülmesi, belli başlı para birimlerinin döviz kuru hareketlerini sınırlamasını da ortadan kaldırmıştır. ${ }^{82}$ Bunun yanında Bretton Woods sisteminin çöküşü ile serbest kur sistemine geçilmesi merkez bankalarının hem kur hem faizi kontrol etmelerine imkân vermiştir. ${ }^{83}$ Bunlar neticesinde piyasa şartları giderek daha belirsiz hale gelmiş ve bu belirsizlik ortamının yarattığı riskler, yatırımcıların riskten korunma ihtiyacını ortaya çıkarmıştır. ${ }^{84}$ Buna benzer üretilmiş risklerin finansallaşmayla birlikte mekânsal sınırının olmaması durumu güvensizliği arttırırken bazı hesaplanabilir risklerin kâr amacıyla kullanılmasının önünü açmıştır. Bu ihtiyacı karşılamak ve belirsizliği, ayırt edilebilir ve ölçülebilir risk haline dönüştürmek noktasında türev ürünler önemli bir rol oynamaktadırlar.

\section{Türev Ürünlerin Ortaya Çıkışı ve Kullanım Amaçları}

1970'ten sonra Bretton Woods'un çökmesi ve esnek kur sisteminin uygulanmaya başlanması piyasalardaki belirsizliğin artmasına sebep olmuştur. Piyasadaki bu belirsizlik, örneğin dövizle ticaret yapan bir yatırımcının, döviz fiyatlarının gelecekte ne seviyede değişeceğini bilmemesinden dolayı büyük bir zarar yaşamamak için bu riskten korunmaya sevk etmiştir. ${ }^{85}$ Yatırımcıların, belirsizlik koşullarının meydana getirdiği riskten korunmak istemesinin bir sonucu olarak türev ürünler ortaya çıkmıştır. ${ }^{86}$ "Türev araçlar, belirsizliği, ayırt edilebilir ve ölçülebilir risk haline dönüştürme ihtiyacını karşılamaktadırlar." ${ }^{87}$ Riskten korunmak isteyenlerin yanında piyasadaki dalgalanma ve riskten faydalanıp kar elde etmek isteyenlerin de türev ürünleri kullanması ve teknolojinin gelişmesiyle işlemlerin anlık yapılabiliyor olması finansal piyasalara olan ilgiyi daha da arttırmıştır. ${ }^{88}$ Burada türev ürünlerin ortaya çıkışı her ne kadar tek bir sebepten (piyasalardaki dalgalanma ve riskin artması) kaynaklanıyor olsa da kullanım amaçlarının zaman içinde farklılaştığı dikkat çekmektedir.

82 Şule Daldal, “Neoliberalizm, Finansallaşma ve Emek Piyasaları”, JOEEP: Journal of Emerging Economies and Policy 1/1 (Aralık 2016), 93.

83 Ahmet Yılmaz \& Ayhan Uçak, "Dünya Ekonomisinde Finansallaşma Sürecinin Eleştirel Bir Değerlendirmesi”, Marmara Üniversitesi İktisadi ve İdari Bilimler Dergisi 33/2 (Mart 2015), 77.

84 Yusuf Şahin, Katılım Bankacılı̆̆ında Türev Ürünler (İstanbul: Marmara Üniversitesi, Bankacılık ve Sigortacılık Enstitüsü, Yüksek Lisans Tezi, 2019), 29.

85 Şahin, Katılım Bankacılı̆̆ında Türev Ürünler, 30.

86 Ersan Ersoy, “Türkiye' de ve Dünyada Organize Türev Piyasaların Gelişimi”, Muhasebe ve Finansman Dergisi 51 (Temmuz 2011), 64.

87 Özşahin, Vadeli İşlem Sözleşmesinin Hukuki Niteliği, 6.

88 Zelal Beyaz, "Ekonomi Politik Perspektiften Finansallaşma ve Finansal İçerilme Sürecinde Dijital Teknolojilerin Yeri", Sosyal Ekonomik Araştırmalar Dergisi 19/38 (Ekim 2019), 109. 


\subsection{Riskten korunma/riski azaltma amaçlı türev ürün kullanımı: Hedging}

Türev ürünlerin ortaya çıkmasındaki en önemli sebep piyasadaki dalgalanmanın oluşturduğu riskten korunma çabalarıdır. Türev ürünler kullanılarak korunmak istenilen riskler "finansal riskler" olarak adlandırılır ve "piyasa riski" "likidite riski" "kredi riski" ve "faaliyet riski" şeklinde dört farklı grupta incelenebilir. ${ }^{89}$ Türev piyasada yaptığ1 işlem ile kur sabitleyen yatırımcı bu farklılığın oluşturacağı kur riskinden korunmuş olacaktır. İşletmeci bugünden işlem yaparak gelecekte oluşabilecek olası değişikliğe karşı fiyatları sabitleyerek finansal risklere karşı koruma altına girmeye çalışmaktadır..$^{90}$ Böylelikle gelecekteki herhangi bir değişiklik kişiyi zarara uğratacak şekilde olsa dahi yaptığı türev sözleşmesi onu bu zarardan koruyacaktır. Tabi kuru sabitlemek için de güncel kur fiyatından daha yüksek bir fiyatı kabul etmek zorunda olacaktır. Güncel kur ve sabit kur arasındaki fark da kuru sabitlemenin getirdiği güvence karşılığında ödenen bir bedel olarak düşünülebilir.

\subsection{Spekülasyon}

Bilgi sistemlerindeki gelişmeler finansal piyasaların ekonomide güçlü bir konum elde etmesindeki önemli etkenlerden biridir. ${ }^{11}$ Teknolojinin gelişmesiyle birlikte daha hızlı şekilde işlem yapma imkanının oluşması türev piyasaların hem işlem hacminin artmasında hem de kullanım amaçlarının farklılaşmasındaki en büyük etmendir. Spekülasyon gelecekte piyasada oluşabilecek değişikliğin lehine olacağını düşünerek kar elde etme amacıyla türev ürünlerin kullanılmasıdır. ${ }^{92}$ Riskten korunma amacıyla türev ürün kullanılmasından sonra en dikkat çeken kullanım amacı risk ortamından faydalanarak kar elde etmektir. ${ }^{93}$ Türev piyasalarda kâr amacıyla pozisyon alan kişilere spekülatör denir. Spekülatörler bir varlığın fiyatının gelecekte artacağını tahmin ediyorsa önceden satın alır ve gelecekte satmak için bekler; eğer varlığın fiyatının düşeceğini tahmin ediyorsa (ve elinde mevcutsa) varlığı bugünden satar ve gelecekte zarara uğrama riskinin altına girmez. ${ }^{94}$ Spekülatörler riskleri üstlenir ve bu risklerden

89 Bulut, Faizsiz Finansta Risk Yönetimi, 25.

90 Sakarya - Akkuş, “Türev Ürünlerin İslami Finans Modelleri Açısından Değerlendirilmesi”, 12.

91 Cafer Kaplan, Finansal Yenilikler ve Piyasalar Üzerine Etkileri: Türkiye Örneği (Türkiye Cumhuriyet Merkez Bankası Araştırma Genel Müdürlüğü, 1999), 8.

92 İstemi Dülger, Finansal Krizler ve Türev Ürünler: Yeni Krizler ve Finansman Araçları (İstanbul: Marmara Üniversitesi, Sosyal Bilimler Enstitüsü, Yüksek Lisans Tezi, 2015), 7.

93 Asad Zaman, "İslam Ekonomisi Umudunun Yeniden Doğuşu”, çev. Ali Can Yenice - Abdullah Talha Genç, International Journal of Islamic Economics and Finance Studies 3/3 (2017), 88.

94 Durmuş, F1khî Açıdan Günümüz Para Mübadelesi Iş̧lemleri, 53. 
gelecekte istenilen durum oluştuğunda kar elde etmeyi amaçlarlar. ${ }^{95}$ Finansal piyasalarda hedging amacıyla işlem yapanlar ile bu riskleri kendilerine transfer ederek kazanç elde etmek isteyen spekülatörler birbirlerinin tamamlayıcısıdır. ${ }^{96}$ Diğer yandan spekülatörler piyasalarda işlem yaptıklarında hareketlenmeye ve büyümeye sebep olmakla birlikte gerçek olmayan fiyatların oluşmasına sebep olabilirler. ${ }^{97}$

\subsection{Arbitraj}

Türev ürünlerin kullanım amaçlarından bir diğeri arbitrajdır. Burada ne hedging şeklinde gelecekte oluşabilecek bir zarardan yani riskten korunma amacı vardır ne de spekülasyon gibi tahmine dayalı pozisyon olarak kar elde etme amacıyla bile bile risk üstlenme vardır. Arbitraj, bir varlığın iki ayrı piyasada farklı fiyatlandırılmasından faydalanarak, varlığın fiyatının düşük olduğu piyasadan satın alınıp yüksek olduğu piyasada satılarak kazanç elde etme işlemidir. ${ }^{88} \mathrm{Bu}$ işlemi yapan arbitrajcı olarak adlandırılan kişi ülkeden ülkeye değişiklik yapan fiyat farkından faydalanmak için hızla pozisyon alması gerektiğinden sürekli diğer ülkelerin finans piyasalarını takip etmek durumundadır. Türev ürünleri kar elde etmek amacıyla kullanılması açısından arbitraj ve spekülasyon benzerlik gösterir. Ancak arbitraj spekülasyondan farklı olarak olası tahminlere göre piyasada işlem yaparak bir risk üstlendiğiniz anlamına gelmez, aksine piyasalar iyi takip ediliyorsa neredeyse- risksiz kazanç söz konusudur.

Risksiz kazanç sağlamaya çalışan çok fazla arbitrajcının olması ve her birinin bir anda uygun fiyatlı piyasaya yönelmesi kısa sürede farklı piyasalardaki fiyatların birbirine yaklaşmasına yol açar. ${ }^{99}$

\section{Finansal Sistemin Problemli Yapısı}

1980'li yılların başından itibaren tüm dünyada uygulamaya konulan neoliberal politikalarla birlikte başlayan küreselleşme sürecinde dünya ekonomisi uluslararası şirketler aracılığıyla piyasa sisteminin denetimi altına girmiştir. ${ }^{100}$ "[N]eoliberalizm her şeyin

95 Eda Tanyel, Türev Ürünler, Türkiye'de ve Dünyada Türev Piyasaların Gelişimi ve Kalkınma ve Yatırım Bankalarında Kullanımı (İller Bankası Anonim Şirketi, Uzmanlık, 2016), 93.

96 Yücel Ayrıçay, "Türev Piyasaların Gelişmekte Olan Piyasalara Olası Etkileri”, Kocaeli Üniversitesi Sosyal Bilimler Enstitüsü Dergisi 5 (Haziran 2003), 8.

97 Dülger, Finansal Krizler ve Türev Ürünler: Yeni Krizler ve Finansman Araçları, 7.

98 Bilal Akkaynak - Suat Yıldırım, “Türev Ürünlerin Kullanım Amaçları: Bist' de Bir Uygulama”, Erzincan Binali Yıldırım Üniversitesi İktisadi ve İdari Bilimler Fakültesi Dergisi 1/2 (Aralık 2019), 26.

99 Ayrıçay, “Türev Piyasaların Gelişmekte Olan Piyasalara Olası Etkileri”, 9.

100 M. Kemal Aydın, “Neoliberal Dalga ya da Küreselleşme”, Bilgi Sosyal Bilimler Dergisi 1 (Haziran 2000), 14. 
finansallaşması, ekonomi dâhil tüm insani alanların metalaşması, hatta günlük yaşamın dahi bir meta haline gelmesini savunur" ${ }^{101}$ İnsanın günlük hayatına ait olan şeylerin piyasaya dahil edilmesiyle piyasanın ekonomi üzerindeki belirleyici rolü toplumun genel ekonomik yapısı üzerinde de hissedilmektedir. Piyasa sisteminin iktisadi faaliyetlerde yönlendirici hatta baskılayıcı olmasının daha ileri bir aşaması finansal piyasaların ekonomiyi yönlendirir konuma yükselmesidir. Çünkü sürecin merkezinde çağdaş ekonomilerin en çok ihtiyaç duyduğu fon transferi vardır. ${ }^{102}$ Finansın ekonomideki bu merkezi karakterine baktığımızda bugün daha da ileri giderek daha fazla finansal kurumlar tarafından yönlendirilen ekonomik bir sistem mevcuttur. ${ }^{103}$ Bir toplumun başarılı ve güçlü olması için o toplumda hizmet veren finansal kurumların eğitim, sağlık, sosyal güvenlik gibi toplumun genel hedefleri veya bir restoranın açılışı gibi toplumdaki bireysel hedefler ile uyum içerisinde olması önemlidir. ${ }^{104}$ Ancak bugün geldiğimiz noktada finansal sistemimizin oldukça hatalı çalıştığını söylemek mümkündür. ${ }^{105} \mathrm{Bu}$ durumun düzeltilmesi için ise toplumun güvenilir bilgiye sahip olması ve finansal kurumların insan yaşamının gerçeklikleri çerçevesinde organize edilmesi gereklidir. ${ }^{106}$ Finansal sitemin güvenli, adil ve memnun edici olması piyasa içinde işlem yapan ya da yapmayan tüm insanlar için önem arz eder. ${ }^{107}$

Neoliberal politikalar ile finans sistemini kontrolsüz olarak serbestleştiren ülkelerde riskler hızla artmaktadır. ${ }^{108}$ Türev ürünlerin kullanım amaçlarından birisi de bu risklerden korunmaktır. Ancak, türev ürünler kullanılarak yapılan risk transferi reel sektör ile finans sektörü arasındaki bağı zayıflatmakta, belirsizliğin ve eşitsizliğin artmasına yol açarak toplum refahının bozulmasına neden olmaktadır. ${ }^{109}$ Toplumun finansal ihtiyaçlarını karşılamakta problemli olan finansal sistem içerisinde önemli bir yere sahip olan türev ürünler; sermaye sahiplerinin kolay yoldan kar elde etmek ve sermayesini arttırmak için spekülasyon ve arbitraj yapmasına olanak sağlayarak toplumda ekonomik adaletsizliği arttırmaktadır. Özetle, toplumun ihtiyaçlarına hizmet etmesi gereken finansal sistem belli kişilerde sermayenin

101 Zafer Çelik, “Neoliberalizmin Kısa Tarihi”, İdealkent 3/7 (Eylül 2012), 189.

102 Aslı Afşar, “Finansal Gelişme ile Ekonomik Büyüme Arasındaki İlişki”, Muhasebe ve Finansman Dergisi 36 (Ekim 2007), 188, 189.

103 Shiller, Finans ve İyi Toplum, 18.

104 Shiller, Finans ve İyi Toplum, 35, 36.

105 Shiller, Finans ve İyi Toplum, 19.

106 Shiller, Finans ve İyi Toplum, 38, 354.

107 Sakarya - Akkuş, “Türev Ürünlerin İslami Finans Modelleri Açısından Değerlendirilmesi”, 272.

108 Cem Okan Tuncel, "Finansal Liberalizasyon ve Küresel Krizin Yapısal Nedenleri: Gelişmekte Olan Ülkeler İçin Dersler", Finans Politik ve Ekonomik Yorumlar Dergisi 47/454 (2010), 12.

109 Adam Ng vd., Sosyal Sermaye ve Risk Paylaşımı, çev. Erhan Akkaş (İstanbul: Albaraka Yayınları, 2020$), 15$. 
birikmesini sağlayarak toplumun ekonomik düzeninin daha kötüye gitmesine sebep olmaktadır.

\section{Finansallaşma Sayesinde Risk Üzerinden Para Kazanılmaya Çalışılması}

Finans sektörü içinde önemli bir konuma sahip olan türev piyasalar özellikle de 1990’l1 yıllardan sonra hem bireysel hem kurumsal yatırımcılar için önemli bir finansal araç haline gelmiştir.110 Teknolojinin sunduğu kolaylıklar ve hızlı işlem yapabilme imkânı finans piyasasının ürünlerini kullanarak sadece riski yönetme amacına değil bunun yanında risk üzerinden para kazanmak için işlem yapılması amacına da hizmet eder olmuştur. "Finansal piyasalar, üretim yatırımlarına aracılık hizmeti veren, fon kaynağı bulma işlevinden çok, reel sektörden ayrışan, daha kısa zamanda daha yüksek getirilerin sağlanabildiği rant piyasasına dönüşmüştür". ${ }^{111}$ Çünkü parayı finansal piyasalarda dolandırarak kar elde etmek onunla katma değer oluşturan reel bir ticari faaliyet gerçekleştirerek kar elde etmekten daha kolaydır ve reel sektörde karın dönmesi ancak uzun vadede mümkün olabilir. ${ }^{112}$ Böylece finansal piyasalarda para ile para kazanmak reel sektörde faaliyet gerçekleştirmenin yanında hem daha kolay hem de kısa vadede daha karlı sayılır.

Finansallaşma ve küreselleşmenin arttığı ekonomik yapı içinde işletmeler gelirlerinin giderek artan bir kısmını daha hızlı, daha kolay ve daha çok kar elde etmek için finans piyasalarına aktarırken kısa vadede kolay kar elde edilmesi mümkün olmayan reel sektör için yatırım azalmaktadır. ${ }^{113}$ Reel sektöre yatırımın azalması özellikle gelişmekte olan ülkelerde işsizlik sorununu beraberinde getirmiştir. ${ }^{114}$ İşsizliğin artması ve emeğin değersizleşmesi ise gelir dağılımı makasının açılmasına sebep olmaktadır.

\section{6. İslam Ekonomisi Açısından Türev Ürünlerin Değerlendirilmesi}

Türev ürünlerin kullanımında mevcut finansal piyasalar açısından kur riski gibi risklere karşı korunma veya piyasaların fiyat dengesine kavuşma gibi sonuçları olsa da

110 Bulut, Faizsiz Finansta Risk Yönetimi, 26.

111 Kamil Uslu \& Aysel Gündoğdu, “Küresel Finansallaşmanın Türkiye’deki Bankaların Finansal Faaliyetlerine ve Bireyler Üzerine Etkileri”, Marmara Üniversitesi İktisadi ve İdari Bilimler Dergisi 31/2 (Mart 2015), 161.

112 Uslu \& Gündoğdu, “Küresel Finansallaşmanın Türkiye'deki Bankaların Finansal Faaliyetlerine ve Bireyler Üzerine Etkileri", 48.

113 Orhangazi, “Keynesgil Finansal Düzenlemelerden Finansallaşmaya: İktisat Literatürü ve ABD Ekonomisinin Finansallaşmasına Tarihsel Bir Bakış", 154.

114 Uslu \& Gündoğdu, "Küresel Finansallaşmanın Türkiye'deki Bankaların Finansal Faaliyetlerine ve Bireyler Üzerine Etkileri”, 152. 
birilerinin kazancı diğer kişilerin kaybı şeklinde olacağı için ${ }^{115}$ daha ziyade servet transferi şeklinde olmakta ve bu işlemler servetin belli kişilerin ellerinde birikmesine yol açabilmektedir. ${ }^{116} \mathrm{Bu}$ akitlerin şekilsel olarak İslam hukukuna uygunluğu tartışmalarını bir kenara bırakacak olsak dahi, bu akitlerin gerçekleştirilme amacı ve toplumsal düzeyde ortaya çıkardığı sonuçlar açısından ele alındığında İslam ekonomisinin ilkelerine uygun olmadığı görülmektedir. Bunun sebebi, toplumun faydasına hizmet etmesi gereken finans sisteminin, ${ }^{117}$ türev ürünler ve benzeri araçların reel ekonomiden kopuk olarak alım-satım işlemlerinde kullanılmasının ekonominin daha da finansallaşmasına yol açması ve sermaye sahibi olan kişilerin finansallaşan bu ekonomide risk üzerinden -göreceli olarak daha az çalışarak- para kazanmasıdır. Bu durum, yukarıda tartışıldığı üzere, işsizlik, emeğin değersizleşmesi ve insanların kolay yoldan gelir elde etme peşinde koşması gibi sonuçlara yol açmaktadır. Finansal araçların reel ekonomi için bir araç olmasını savunan İslam ekonomisi açısından bu dönüşüm olumsuz görülmektedir.

Öte yandan, firmaların sermayesi büyüdükçe ithalat ve ihracat yaparak küresel ekonomiye dahil olmakta ve maruz kaldığı riskte küresel ekonomiye girdiği nispette büyümektedir. Sermayesi büyüyen firmalar artık yöneten değil yönetilen konumuna geçer. ${ }^{118}$ Çünkü firmalar küresel ekonomide maruz kaldığı risklerden korunma zorunluluğu ile karş1 karşıyadır. ${ }^{119}$ Küresel ekonomide sürekli büyüme sağlayamadığında veya maruz kaldığ1 risklerden korunamadığında piyasada kalması zorlaşacaktır. Diğer yandan “Küçük ve Orta Ölçekli İşletmeler"e dahil olan göreceli olarak az sermayeye sahip firmalar da -ithalat veya ihracat ile ilgileniyorsa- kur riski ile karşı karşıyadır ve ileri bir tarihte kurda oluşabilecek bir değişiklik küçük sermaye ile ticari faaliyet gösteren firmayı da elbette etkileyecektir.

İster büyük sermaye ile iktisadi faaliyet gerçekleştirerek küresel ekonomiye dahil olanlar olsun ister daha küçük sermaye ile iktisadi faaliyet gerçekleştirenler olsun neticede türev ürünler kullanılarak olası riski bertaraf etme yolu seçilmektedir. Türev ürünler ile aslında kişinin maruz kaldığı risk tamamen ortadan kalkmamakta, firma riskten korunmak için belirli bir bedel ödemeye razı olmaktadır. Bu bedeli ödemekle gelecekteki muhtemel riskin ortadan kaldırılması değil riskten korunma yani risk gerçekleşse dahi riskten etkilenmemesini

115 Özşahin, Vadeli İşlem Sözleşmesinin Hukuki Niteliği, 8.

116 Bayındır, "Finansal Türev Varlıklar ve Bu Varlıklar Üzerine Yapılan Sözleşmelerin Fıkhî Tahlili”, 73.

17 Shiller, Finans ve İyi Toplum, 35.

118 Abdurrahman Babacan, Piyasa Akli ve Yeni Muhafazakar Ahlak (İstanbul: İz Yayıncılık, 2018), 244-245.

119 Sinan Atik, Küreselleşme ve Küresel İşletmeler (İstanbul: Kadir Has Üniversitesi, Sosyal Bilimler Enstitüsü, Yüksek Lisans Tezi, 2007), 73. 
sağlamaktadır. Günümüz piyasalarında temelde üç şeyin ticareti yapılmaktadır; mal, hizmet ve risk. ${ }^{120}$ İlk ikisi kurallara uygun gerçekleştirildiği takdirde fikhen meşru görülürken çağdaş fakihlerin çoğunluğu -özellikle sigorta ürünlerini değerlendirirken- riskin ticarete konu bir meta olamayacağını ileri sürmektedir. ${ }^{121}$ Bununla beraber, literatür taraması kısmında da detaylı olarak ele alındığı üzere türev ürünlerin fıkhi değerlendirilmesi sırasında mevcut finans piyasalarında riskin metalaşması durumu değerlendirmeye alınmamış, caiz görmeyen İslam hukukçuları sözleşmedeki başka sorunlar üzerinden konuyu tartışmışlardır.

İslami ekonomisinde riskin meta olamayacağından yola çıkarak türev ürünler kullanılmasını doğru bulmayanlar bir yana bir de konuya kişinin ve toplumun maslahatı açısından bakılmaktadır. Uluslararası ticaret yapan bir kişi için kur riskinden korunması bir ihtiyaç arz etmekte ise de vadeli döviz işlemler faizli bir işlem mahiyetinde olmasından dolayı toplumun geneline zarar vermektedir. ${ }^{122}$ Burada türev ürünleri kullanmak her ne kadar bireyin çıkarına ve menfaatine olsa da toplumun genelinin maslahatı onun üstünde görülmektedir ve İslam hukukundaki genel kabule göre toplumun maslahatı karşısında daha az zararlı olan tercih edilmelidir. ${ }^{123}$

Bugün toplumun ihtiyaçlarına cevap vermekte sorunlu görülen finans sisteminde risk transferi kullanılmaktadır. Ancak toplumda adalet ve sosyal refahın sağlanması için İslam'ın uygun gördüğü yöntem risk paylaşımıdır.124 Tek tarafın kaybetmesine zemin hazırlayan işlemler ise İslam dininde yasak olan kumara benzemektedir. İslam servetin belirli ellerde dolaşmasını yasaklamıştır ve İslam ekonomisi toplumda bulunan tüm bireylerin ihtiyaçlarının karşılanmasını sağlayacak bir sistemi savunur. Riskin gerçek bir tehdit olduğu kabul edilmektedir ve İslami finans sektörünün amaçlarına ulaşması için orta ve uzun vadeli risk paylaşım araçlarının geliştirilmesi gereklidir. ${ }^{125}$

\footnotetext{
120 Servet Bayındır, Fıkhi ve İktisadi Açıdan İslami Finans 2 (İstanbul: Süleymaniye Vakfı Yayınları, 2015 ), 61.

121 Bayındır, Fıkhi ve İktisadi Açıdan İslami Finans 2, 61.

122 Durmuş, Fıkhî Açıdan Günümüz Para Mübadelesi İşlemleri, 100.

123 Durmuş, Fıkĥ̂ Açıdan Günümüz Para Mübadelesi Isşlemleri, 100.

124 Necmettin Kizılkaya (ed.), İslam ve Finans (İstanbul: İSAR Yayınları, 2019), 240.

$125 \mathrm{Ng}$ vd., Sosyal Sermaye ve Risk Paylaşımı, 221.
} 


\section{Sonuç}

$\mathrm{Bu}$ çalışmada türev ürünlerin kullanılması konusunu riskin arttığ1 ve artık örtük olmadığı günümüzde hedging amaçlı kullanılması ve ekonomide küreselleşmenin verdiği imkanlar sayesinde spekülasyon ve arbitraj amaçlı kullanılması şeklinde iki açıdan ele aldık. Küreselleşme ve finansallaşmanın yarattığı risk ortamında türev ürünlerin hedging amaçlı kullanılması her ne kadar reel sektörün maruz kaldığı riski azaltmasını sağlayarak faydalı görünse de riski meta haline getirmektedir. Riskin meta haline geldiği türev piyasalar ise daha kolay ve daha kısa sürede sermaye birikimine hizmet ederek kapitalist bir bakış açısıyla spekülasyon ve arbitraj yapmayı sağlamaktadır. Sonuç olarak reel sektöre faydalı gibi görünen hedging amaçlı işlemler de risk üzerinden para kazanmayı sağlayan spekülasyon ve arbitraj amaçlı işlemler de toplum ihtiyaçlarını göz ardı ederek belli gruplarda sermaye birikimi sağlayan ve bu yüzden problemli olan finans piyasasının hacmini büyütmekte ve bu durumda yine reel ekonomiyi olumsuz etkilemektedir. İslami açıdan düşünüldüğünde ise riskin türev ürünler aracılığıyla meta haline gelmesi yine sorunlu kabul edilmektedir. Öte yandan spekülasyon ve arbitraj yapılarak belli bir grubun elinde sermayenin toplanması ve toplum içinde ekonomik adaletin bozulmasına hizmet eden ekonomik faaliyetler İslam ahlakına uygun değildir. Bu yüzden riski meta haline getiren işlemler yerine İslam ekonomisi anlayışına uygun risk paylaşımına dayalı kurumların inşa edilmesi gereklidir. 


\section{Kaynakça}

Afşar, Aslı. "Finansal Gelişme ile Ekonomik Büyüme Arasındaki İlişki". Muhasebe ve Finansman Dergisi 36 (Ekim 2007), 188-198.

Akkaynak, Bilal - Yıldırım, Suat. “Türev Ürünlerin Kullanım Amaçları: Bist' de Bir Uygulama". Erzincan Binali Yıldırım Üniversitesi İktisadi ve İdari Bilimler Fakültesi Dergisi 1/2 (Aralık 2019), 23-33.

Aksoy, Ahmet - Tanriöven, Cihan. Sermaye Piyasası Yatırım Araçları ve Analizi. Ankara: Gazi Kitabevi, 3., 2007.

Aktepe, İshak Emin. Katılım Finans. İstanbul: Türkiye Katılım Bankaları Birliği Yayınları, 2017, 09.

Aktepe, İshak Emin. Sorularla Katılım Bankacılığı. İstanbul: Türkiye Katılım Bankaları Birliği, 2013.

Alkeback, Per - Hagelin, Niclas. "Derivative Usage by Nonfinancial Firms in Sweden with an International Comparison". Journal of International Financial Management $\mathcal{E}$ Accounting 10/2 (1999), 105-120.

Askari, Hossein vd. The Stability of Islamic Finance: Creating a Resilient Financial Environment for a Secure Future. Singapore: John Wiley \& Sons (Asia) Pte. Ltd., 2010.

Asutay, Mehmet. "A Political Economy Approach to Islamic Economics: Systemic Understanding for an Alternative Economic System". Kyoto Bulletin of Islamic Area Studies 1/2 (2007), 3-18.

Asutay, Mehmet. "Conceptualising and Locating the Social Failure of Islamic Finance: Aspirations of Islamic Moral Economy Vs the Realities of Islamic Finance". Asian and African area studies 11/2 (2012), 93-113.

Atik, Sinan. Küreselleşme ve Küresel İşletmeler. İstanbul: Kadir Has Üniversitesi, Sosyal Bilimler Enstitüsü, Yüksek Lisans Tezi, 2007.

Aydın, Aytaç. İslam Hukuku Açısından Mali Piyasa ve Mali Piyasa Araçları. Konya: Burç Yayınevi, 2. Basim, 2015.

Aydın, M.Kemal. "Neoliberal Dalga ya da Küreselleşme”. Bilgi Sosyal Bilimler Dergisi 1 (Haziran 2000), 13-27.

Ayrıçay, Yücel. “Türev Piyasaların Gelişmekte Olan Piyasalara Olası Etkileri”. Kocaeli Üniversitesi Sosyal Bilimler Enstitüsü Dergisi 5 (Haziran 2003), 1-19.

Babacan, Abdurrahman. Piyasa Aklı ve Yeni Muhafazakar Ahlak. İstanbul: İz Yayıncılık, 2018.

Bayındır, Servet. Fıkhi ve İktisadi Açıdan İslami Finans 2. İstanbul: Süleymaniye Vakfı Yayınları, 2015.

Bayındır, Servet. "Finansal Türev Varlıklar ve Bu Varlıklar Üzerine Yapılan Sözleşmelerin Fikhî Tahlili”. İstanbul Üniversitesi İlahiyat Fakültesi Dergisi 0/12 (May1s 2012), 51-73.

Beck, Ulrich. Risk Toplumu \& Başka Bir Modernliği Doğru. çev. Bülent Doğan - Kazım Özdoğan. İstanbul: İthaki Yayınları, 3. Basım, 2019.

Beyaz, Zelal. "Ekonomi Politik Perspektiften Finansallaşma ve Finansal İçerilme Sürecinde Dijital Teknolojilerin Yeri”. Sosyal Ekonomik Araştırmalar Dergisi 19/38 (Ekim 2019), 99117.

Bulut, Erkam Haşim. Faizsiz Finansta Risk Yönetimi. İstanbul: İstanbul Üniversitesi, Sosyal Bilimler Enstitüsü, Yüksek Lisans Tezi, 2019.

Brunzell, Tor vd. "The Use of Derivatives in Nordic Firms". The European Journal of Finance 17/5-6 (2011), 355-376.

Çelik, Zafer. “Neoliberalizmin Kısa Tarihi”. IDEALKENT 3/7 (Eylül 2012), 187-193. 
Çuhac1, Aysu. "Ulrich Beck'in Risk Toplumu Kuramı". İstanbul Üniversitesi Sosyoloji Dergisi 3/14 (Şubat 2012), 129-157.

Daldal, Şule. "Neoliberalizm, Finansallaşma ve Emek Piyasaları". JOEEP: Journal of Emerging Economies and Policy 1/1 (Aralık 2016), 85-104.

Darîr, es-Siddîk Muhammed el-Emîn ed-. "el-İhtiyârât". Mecelletü Mecmai'l-Fikhi'l-İslâmî 7/1 (1992), 261-272.Dikkaya, Mehmet - Deniz, Fatih. “Ekonomik Küreselleşmenin Yol Açtığ1 Problemler: Teorik Bir Bakış". Uluslararası Yönetim İktisat ve İşletme Dergisi 2/3 (Haziran 2006), 163-181.,

Dinler, Zeynel. İktisada Giriş. Bursa: Ekin Yayınevi, 25. Basım, 2019.

Döndüren, Hamdi. Ticaret ve İktisat İlmihali. İstanbul: Erkam Yayınları, 2012. Basım, ts.

Durmuş, Abdullah. “Döviz Vadeli ve Emtia Vadeli İşlem Sözleşmeleri”. II. Uluslararası İslam

Ticaret Hukuku Kongresi "Günümüzdeki Meseleler". ed. Mehmet Bayyiğit. 977-990. Konya: KTO Karatay Üniversitesi Yayınları, 2016.

Durmuş, Abdullah. Fıkhî Açıdan Günümüz Para Mübadelesi İşlemleri. İstanbul: İsam Yayınları, 2. Basim, 2014.

Dülger, İstemi. Finansal Krizler ve Türev Ürünler: Yeni Krizler ve Finansman Araçları. İstanbul: Marmara Üniversitesi, Sosyal Bilimler Enstitüsü, Yüksek Lisans Tezi, 2015.

Eğilmez, Mahfi. Ekonominin Temelleri (Kavramlar ve Kurumlar). İstanbul: Remzi Kitabevi, 3. Basım, 2019.

Emhan, Abdurrahim. "Risk Yönetim Süreci ve Risk Yönetmekte Kullanılan Teknikler". Atatürk Üniversitesi İktisadi ve İdari Bilimler Dergisi 23/3 (Ağustos 2010), 209-220.

Ersoy, Ersan. “Türkiye'de ve Dünyada Organize Türev Piyasaların Gelişimi”. Muhasebe ve Finansman Dergisi 51 (Temmuz 2011), 63-80.

Esgin, Ali. “İmal Edilmiş Belirsizlikler Çağının Sosyolojik Yönelimi: Ulrich Beck ve Anthony Giddens Kaynaklı 'Risk Toplumu' Tartışmaları”. Gaziantep University Journal of Social Sciences 12/3 (Aralık 2013), 683-696.

Faizsiz Finans Kuruluşları Muhasebe ve Denetleme Kurumu (AAOIFI). Faizsiz Finans Standartları. İstanbul: Türkiye Katılım Bankaları Birliği Yayınları, 2015, Yayın no:10.

Giddens, Anthony. Sosyoloji. çev. Hüseyin Özel vd. İstanbul: Kırmızı yayınları, 5. Basım, 2012. Kaplan, Cafer. Finansal Yenilikler ve Piyasalar Üzerine Etkileri: Türkiye Örneği. Türkiye Cumhuriyet Merkez Bankası Araştırma Genel Müdürlüğü, 1999.

Kahveci, Nuri (ed.). İslam Hukuku (Eşya-Borçlar-Şirketler). 2 Cilt. İstanbul: Hikmetevi Yayınları, 2020.

Kamali, Mohammad Hashim. İslam Ticaret Hukuku Vadeli İşlem Sözleşmeleri ve Opsiyonların Analizi. çev. Nazan Lila. İstanbul: Albaraka Yayınları, 2020.

Karadâği, Ali Muhyiddin. “"el-Esvâkü'l-mâliyye fî mizâni'l-fıkhi'l-İslâmî”. Mecelletü Mecmai'l-Fıkhi'l-İslâmî7/1 (1992), 73-194.

Karatepe, Yalçın. Türev Piyasaları. Ankara: Ankara Üniversitesi Siyasal Bilimler Fakültesi Yayını, 2000, Yayın no:587.

Mergînânî, Burhânüddîn Alî b. Ebî Bekr el-. el-Hidaye Tercümesi. çev. Hüseyin Vanlıŏ̆lu vd. 7 Cilt. İstanbul: Yasin Yayınevi, 2017.

Muhammad Al-Amine, Muhammad Al-Bashir. İslami Finansta Risk Yönetimi E Emtia Piyasalarındaki Türev Ürünler Üzerine Bir İnceleme. çev. Ali Kürşat Sak - Gencay Karakaya. İstanbul: Albaraka Yayınları, 2020.

$\mathrm{Ng}$, Adam vd. Sosyal Sermaye ve Risk Paylaşımı. çev. Erhan Akkaş. İstanbul: Albaraka Yayınları, 2020. 
Orhangazi, Özgür. “Keynesgil Finansal Düzenlemelerden Finansallaşmaya: İktisat Literatürü ve ABD Ekonomisinin Finansallaşmasına Tarihsel bir Bakış”. ODTÜ Gelişme Dergisi 35 (Haziran 2008), 133-159.

Özşahin, A.Kerem. Vadeli İşlem Sözleşmesinin Hukuki Niteliği. Ankara: Sermaye Piyasası Kurulu, Yeterlilik $\quad 1999$. https://www.spk.gov.tr/SiteApps/Yayin/YayinGoster/471

Polanyi, Karl. Büyük Dönüşüm: Çă̆ımızın Siyasal ve Ekonomik Kökenleri. çev. Ayşe Buğra. İstanbul: İletişim Yayınları, 9. Basım, 2010.

Sakarya, Şakir - Akkuş, Hilmi Tunahan. "Türev Ürünlerin İslami Finans Modelleri Açısından Değerlendirilmesi". Adam Akademi Sosyal Bilimler Dergisi 8/2 (Aralık 2018), 267-299.

Sâlûs, Ali Ahmed. el-Muâmelâtü'l-mâliyye el-muâsıra fì mîzâni'l-fikhi'l-İslâmî. Kuveyt: Mektebetül'1-Fellah, 3. Basım, 1992.

Shiller, Robert J. Finans ve İyi Toplum. çev. Erhan Akkaş. İstanbul: Albaraka Yayınları, 2019.

Soydemir, Suat. "Modernizmin Karanlık Yüzü: Risk Toplumu”. Sosyal ve Beşeri Bilimler Dergisi 3/2 (01 Aralık 2011), 169-178.

Şahin, Yusuf. Katılım Bankacılı̆̆ında Türev Ürünler. İstanbul: Marmara Üniversitesi, Bankacılık ve Sigortacilık Enstitüsü, Yüksek Lisans Tezi, 2019.

Şahin, Şamil. “Ukûdü'l-müstakbeliyyât fi's-sila'". İslam Medeniyet Dergisi 7/47 (Haziran 2021), 65-71.

Takî el-Osmânî, Muhammed. “Ukûdü'l-müstakbeliyyât fi's-sila'”. Mecelletü Mecmai'l-Fıkhi'lİslâmî 1/7 (1992), 341-356.

Tanyel, Eda. Türev Ürünler, Türkiye'de ve Dünyada Türev Piyasaların Gelişimi ve Kalkınma ve Yatırım Bankalarında Kullanımı. İller Bankası Anonim Şirketi, Uzmanlık, 2016.

Tuncel, Cem Okan. “Finansal Liberalizasyon ve Küresel Krizin Yapısal Nedenleri: Gelişmekte Olan Ülkeler İçin Dersler". Finans Politik ve Ekonomik Yorumlar Dergisi 47/454 (2010), 28.

Uslu, Kamil \& Gündoğdu, Aysel. “Küresel Finansallaşmanın Türkiye'deki Bankaların Finansal Faaliyetlerine ve Bireyler Üzerine Etkileri". Marmara Üniversitesi İktisadi ve İdari Bilimler Dergisi 31/2 (Mart 2015), 145-164.

Yaman, Ahmet. "Yeni Zamanlarda Fetvaya Ne Oldu? Günümüz Fetvalarında Görülen Bazı Yöntem Sorunları". Türkiye Araştırmaları Literatür Dergisi 13/25-26 (2015), 9-36.

Yildırım, Engin. "Risk Toplumunda (Depremle) Yaşamak". Akademik İncelemeler Dergisi 3/1 (Ağustos 2014), 75-85.

Y1lmaz, Ahmet \& Uçak, Ayhan. “Dünya Ekonomisinde Finansallaşma Sürecinin Eleştirel Bir Değerlendirmesi". Marmara Üniversitesi İktisadi ve İdari Bilimler Dergisi 33/2 (Mart 2015), 67-84.

Zaman, Asad. "İslam Ekonomisi Umudunun Yeniden Doğuşu”, çev. Ali Can Yenice Abdullah Talha Genç, International Journal of Islamic Economics and Finance Studies 3/3 (2017), 88. 